\title{
The presence of mu-, delta-, and kappa-opioid receptors in human heart tissue
}

\author{
Piotr Sobanski • Malgorzata Krajnik • \\ Mohammed Shaqura $\cdot$ Elzbieta Bloch-Boguslawska • \\ Michael Schäfer · Shaaban A. Mousa
}

Received: 22 September 2013/ Accepted: 13 December 2013/Published online: 5 January 2014

(C) Springer Japan 2014

\begin{abstract}
Functional evidence suggests that the stimulation of peripheral and central opioid receptors (ORs) is able to modulate heart function. Moreover, selective stimulation of either cardiac or central ORs evokes preconditioning and, therefore, protects the heart against ischemic injury. However, anatomic evidence for OR subtypes in the human heart is scarce. Human heart tissue obtained during autopsy after sudden death was examined immunohistochemically for mu- (MOR), kappa- (KOR), and delta- (DOR) OR subtypes. MOR and DOR immunoreactivity was found mainly in myocardial cells, as well as on sparse individual nerve fibers. KOR immunoreactivity was identified predominantly in myocardial cells and on intrinsic cardiac adrenergic (ICA) cell-like structures. Double immunofluorescence confocal microscopy revealed that DOR colocalized with the neuronal marker PGP9.5, as well as with the sensory neuron marker calcitonin gene-related peptide
\end{abstract}

P. Sobanski $(\bowtie)$

Palliativzentrum Hildegard, Basel, Switzerland

e-mail: psoban@wp.pl

P. Sobanski

Gynaecological Cancer Center, University Hospital Basel, Basel, Switzerland

M. Krajnik

Palliative Care Department, Nicolaus Copernicus University,

Ludwik Rydyger Collegium Medicum, Bydgoszcz, Poland

M. Shaqura · M. Schäfer · S. A. Mousa

Department of Anesthesiology and Intensive Care Medicine, Charité University Berlin, Campus Virchow Klinikum and

Campus Charite Mitte, Berlin, Germany

E. Bloch-Boguslawska

Department of Forensic Medicine, Nicolaus Copernicus

University, Ludwik Rydyger Collegium Medicum, Bydgoszcz, Poland
(CGRP). CGRP-immunoreactive (IR) fibers were detected either in nerve bundles or as sparse individual fibers containing varicose-like structures. Our findings offer the first hint of an anatomic basis for the existence of OR subtypes in the human heart by demonstrating their presence in CGRPIR sensory nerve fibers, small cells with an eccentric nucleus resembling ICA cells, and myocardial cells. Taken together, this suggests the role of opioids in both the neural transmission and regulation of myocardial cell function.

Keywords Human heart · Opioid receptor · Sensory neuron $\cdot$ Immunohistochemistry

\section{Introduction}

There is a growing body of data supporting a peripheral role for opioids in the regulation of organ function, such as the gut [1], lungs [2, 3], and heart [4]. Experimental studies have shown that stimulation of both peripheral (cardiac) and central opioid receptors (ORs) is able to modulate heart function and evoke cardioprotection against ischemia [5-7]. The efficacy of opioids in inducing preconditioning and postconditioning not only in intact hearts in vivo [8] but also in isolated cardiomyocytes in vitro $[9,10]$, their inotropic effects [11-13], and their impact on growth factor expression $[14,15]$ in cell culture indicate the presence of ORs on cardiomyocytes and not only on neural elements.

The function of the heart is controlled by the autonomic nervous system. It is widely accepted that the heart has an intrinsic cardiac nervous system, or "heart brain," consisting of a complex network of intrinsic cardiac ganglia, sensory afferents, local circuits, and pre- and postganglionic parasympathetic and postganglionic sympathetic 
efferents. We have consistently shown in rats that mu-OR (MOR), delta-OR (DOR), and kappa-OR (KOR) are expressed as mRNA and translated into specific receptor proteins on different components of the intrinsic cardiac nervous system [16, 17].

To date, anatomic evidence for the different OR subtypes in the human heart has been scarce. Most investigators have confirmed the presence of DOR mRNA and protein, but there is still conflicting evidence for MOR and KOR [18-20]. Moreover, immunohistochemical studies of their anatomic distribution are lacking. Therefore, we examined the presence of MOR, DOR, and KOR throughout human heart tissue sampled from victims of sudden death.

\section{Materials and methods}

Patients and the preparation of human heart tissue

The study protocol adhered to the International Guidelines of the Declaration of Helsinki 2004 (World Medical Association: http://www.wma.net) and was approved by the Ethics Committee of the Nicolaus Copernicus University in Torun, Poland. Human heart tissue samples were obtained from two subjects (females, 37 and 42 years of age) up to $48 \mathrm{~h}$ after sudden death during postmortem examination in the Forensic Medicine Department, Bydgoszcz. The younger female died as a result of suicide. The older female died unexpectedly and during autopsy, atherosclerotic changes in the coronaries and focuses of myolysis and nuclear fragmentation were identified, which gave the suspicion of a very recent myocardial infarction. Both were nonsmokers. Samples (at least $1 \mathrm{~cm}^{3}$ each) were taken from five different regions, two from each location: the right atrium between the caval veins, the free wall of the right ventricle, the intraventricular septum, the anterior wall of the left ventricle including the left anterior descending coronary artery, and the inferior wall of the left ventricle. Tissue samples were fixed in $4 \%(\mathrm{w} / \mathrm{v})$ paraformaldehyde in $0.16 \mathrm{M}$ phosphate buffer solution ( $\mathrm{pH} 7.4$ ) for $5 \mathrm{~h}$ and then cryoprotected overnight at $4{ }^{\circ} \mathrm{C}$ in phosphate-buffered saline (PBS) containing $10 \%$ sucrose [21]. The tissues were embedded in Tissue-Tek compound (OCT; Miles, Elkhart, IN, USA). Then 50- $\mu \mathrm{m}$ thick sections were processed in a cryostat and collected in PBS (floating sections).

Single immunostaining for light microscopy

Floating tissue sections were processed for MOR, DOR, or KOR immunohistochemistry with a Vectastain avidinbiotin-peroxidase complex (ABC) kit (Vector
Laboratories, Burlingame, CA, USA) as described previously [21, 22]. All incubations were carried out at room temperature, and PBS was used for washing (three times for $10 \mathrm{~min}$ ) after each step. Sections were incubated for $45 \mathrm{~min}$ in PBS with $0.6 \% \mathrm{H}_{2} \mathrm{O}_{2}$ and $50 \%$ methanol to block endogenous peroxidase, and for 60 min in PBS containing $0.3 \%$ Triton X-100, $1 \%$ bovine serum albumin, and $10 \%$ goat serum (Vector Laboratories) (blocking solution) to prevent nonspecific binding. The sections were then incubated overnight with polyclonal rabbit antibodies against MOR (a gift from $\mathrm{S}$. Schulz and V. Höllt, Magdeburg, Germany), DOR (a gift from R. Elde, Minneapolis, MN, USA), or KOR (a gift from S.J. Watson, MI, USA), and thereafter for $90 \mathrm{~min}$ with a goat antirabbit biotinylated secondary antibody (Vector Laboratories) and for another $90 \mathrm{~min}$ with $\mathrm{ABC}$. Finally, specific immunostaining was detected with $3^{\prime}, 3^{\prime}$ disaminobenzidine tetrahydrochloride (Sigma, Taufkirchen, Germany). Rabbit polyclonal anti-MOR, anti-DOR, and anti-KOR have been thoroughly characterized previously [16, 17, 23]. Their immunoreactivity is lost upon gene deletion of the respective receptors in transgenic animals [24] or on Western blot following preincubation with the respective antigen peptide [16, 17, 23]. In addition, there is no cross-reactivity between these antisera, since they do not stain the other receptors following their respective transfection into cell lines [25-27].

\section{Double immunofluorescence staining}

Double immunofluorescence staining was performed as described previously [22]. In brief, floating tissue sections were incubated for $60 \mathrm{~min}$ in blocking solution. The sections were then incubated overnight with the following antibodies: (1) rabbit polyclonal anti-DOR (dilution: $1: 1000)$ in combination with chicken polyclonal protein gene product 9.5 (PGP9.5) antibody (dilution: 1:500; EnCor Biotechnology, Gainesville, FL, USA) or guinea pig polyclonal calcitonin gene-related peptide (CGRP) antibody (dilution: 1:500; Peninsula Laboratories, San Carlos, CA, USA). After incubation with primary antibodies, the tissue sections were washed with PBS and then incubated with the appropriate secondary antibodies. After incubation with primary antibodies, the tissue sections were washed with PBS and then incubated with Texas Red conjugated goat antirabbit antibody (Vector Laboratories) in combination with Alexa Fluor 488 goat anti-guinea pig or antichicken antibody (Invitrogen, Karlsruhe, Germany). Thereafter, sections were washed with PBS, and the nuclei stained bright blue with 4'-6-diamidino-2-phenylindole $(0.1 \mu \mathrm{g} / \mathrm{ml}$ in PBS) (Sigma). Finally, the tissues were 
washed in PBS, mounted in Vectashield (Vector Laboratories), and imaged on a confocal laser scanning microscope, Zeiss LSM 510 (Carl Zeiss, Göttingen, Germany). To demonstrate specificity of staining, the following controls were included as described thoroughly in detail elsewhere [16, 17, 28-30]: (1) preabsorption of diluted antibody against MOR, DOR, or KOR with $5 \mu \mathrm{g} / \mathrm{ml}$ of synthetic peptide antigen for MOR (Gramsch Laboratories, Schwabhausen, Germany), DOR (Neuromics, Minneapolis, MN, USA), or KOR (S.J. Watson), respectively, for 24 $\mathrm{h}$ at $4{ }^{\circ} \mathrm{C}$; and (2) omission of either the primary or secondary antibodies.
A
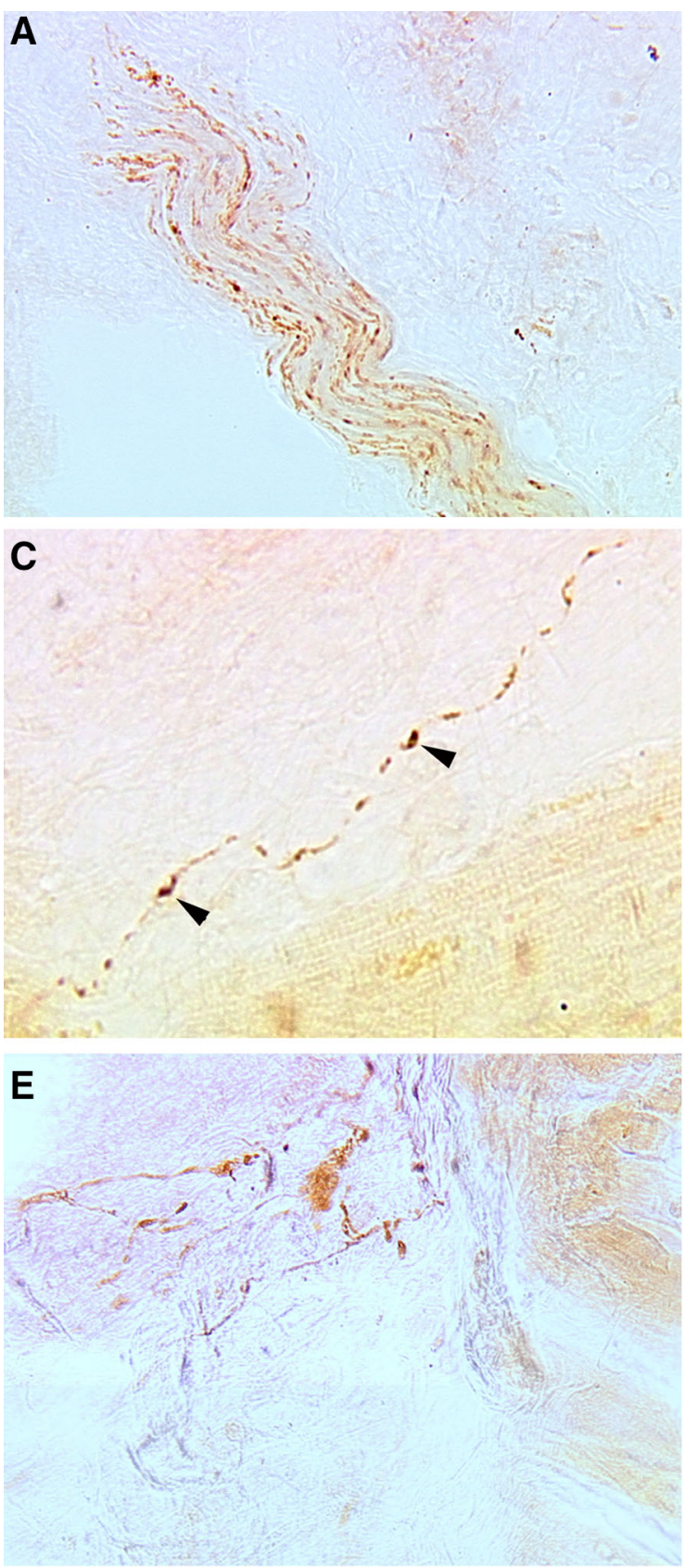

Fig. 1 Immunohistochemical localization of calcitonin gene-related peptide (CGRP) in the right and left ventricles of human heart tissue. a CGRP immunoreactivity expressed in nerve processes coursing in nerve bundles. b-d CGRP immunoreactivity localized to some nerve processes arborizing throughout the right ventricle tissue, containing
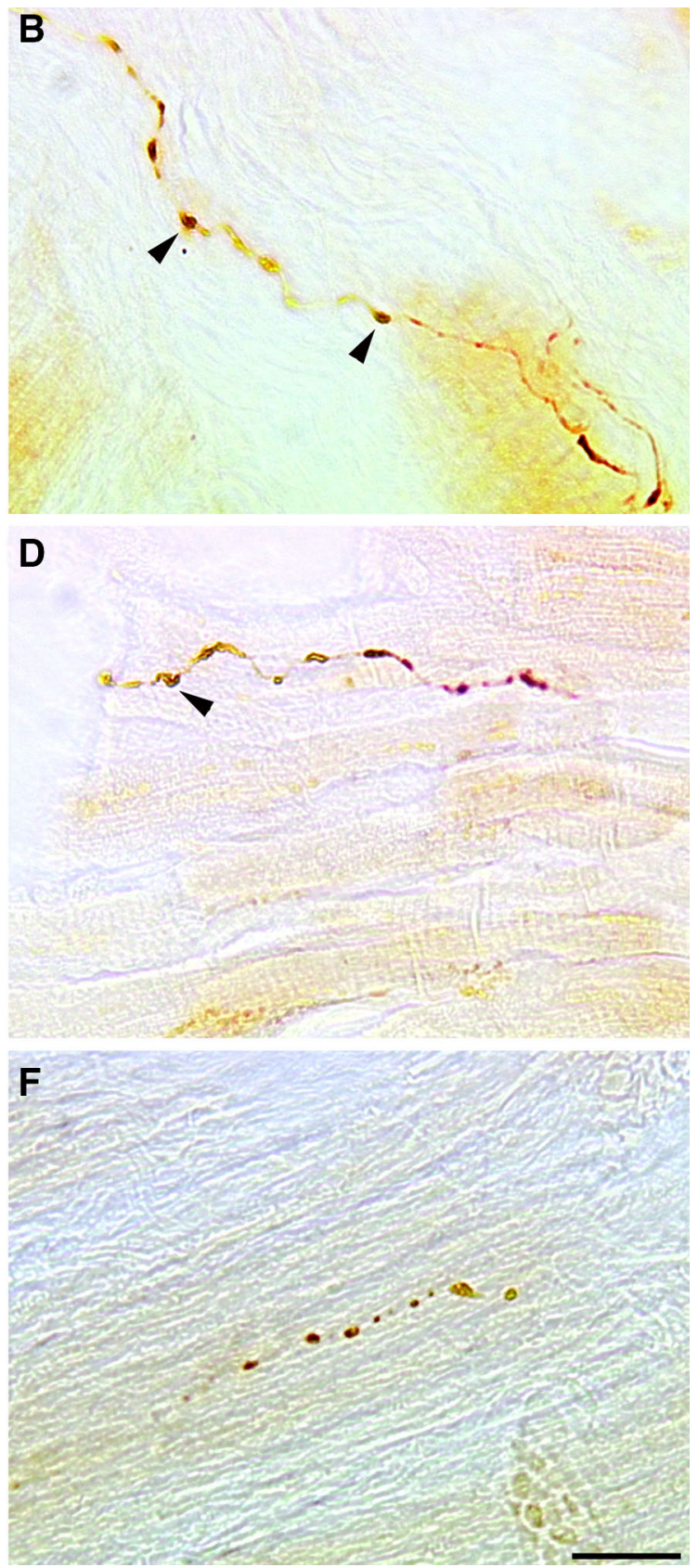

localized bead-like enlargements of the axoplasm (arrowheads) along their lengths. c, f CGRP immunohistochemical localization in the left ventricle. Note that CGRP is expressed in sparse, fine, and varicose nerve fibers. Bar $20 \mu \mathrm{m}$ 


\section{Results}

Identification of CGRP-immunoreactive sensory nerve fibers in human myocardial tissue

In the right ventricle of the human heart, the majority of CGRP immunoreactivity consisted of nerve processes coursing in nerve bundles together with nonstained nerve processes (Fig. 1a-d). In addition, CGRP-stained individual nerve fibers arborizing throughout the right ventricle myocardium contained localized, bead-like enlargements of the axoplasm along their course. Histologically, these enlargements resembled varicosities. In the free wall of the left ventricle, sensory nerve fibers were usually sparse, fine, and varicose, and exhibited CGRP immunoreactivity (Fig. 1e, f). An abundant supply of CGRP-immunoreactive (IR) nerve bundles and varicose nerve fibers was distributed throughout the intraventricular
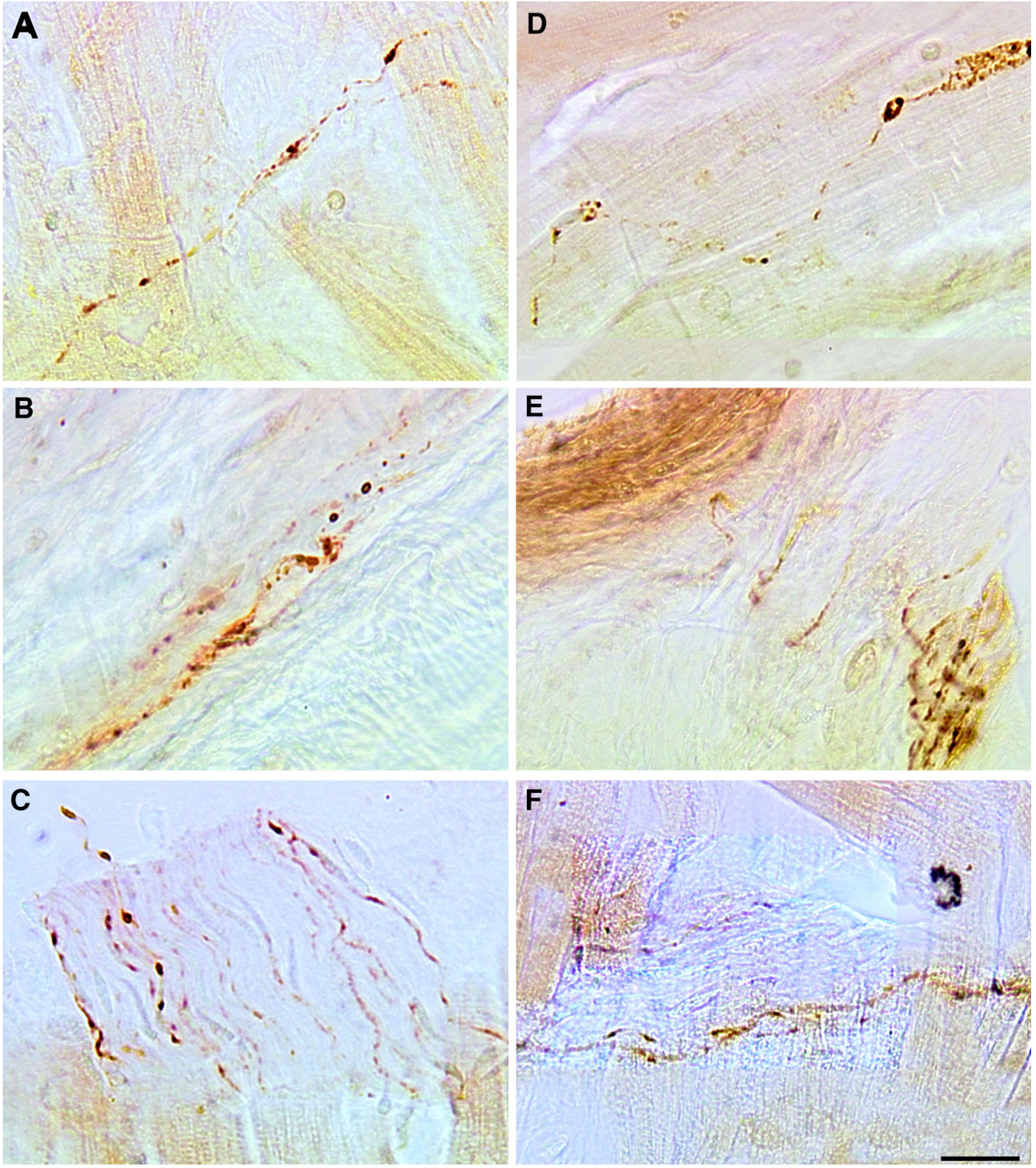

Fig. 2 Immunohistochemical localization of CGRP immunoreactivity in the intraventricular septum (a-e) and right atrium (f) of human nerve trunks (b, c), nerve fascicles (e), and varicose nerve fibers (a, d). $\mathbf{f}$ CGRP in the right atrium. Note that CGRP is expressed in sparse, fine, and varicose nerve fibers. Bar $20 \mu \mathrm{m}$ 
septum (Fig. 2a-e). Single CGRP-IR nerve fibers in the right atrium were usually sparse, fine, and varicose (Fig. $2 f)$.

Identification of MOR, DOR, and KOR immunoreactivity in human myocardial tissue

Light microscopy pictures of human myocardium immunostained with a specific antibody against MOR identified a high degree of MOR immunoreactivity inside myocardial cells in the inferior wall of the left ventricle (Fig. 3a, b). In addition, MOR immunoreactivity was demonstrated in sparse fine nerve fibers taking their course through human myocardium in the intraventricular septum and inferior wall of the left ventricle (Fig. 3c).

Delta opioid receptors (DOR) immunoreactivity was located in the free wall of the right ventricle and in the intraventricular septum, predominantly on longitudinal structures corresponding to nerves. Some of the DOR-IR thin nerve fibers were in close proximity to small artery walls (Fig. 3e), whereas others lay between cardiomyocytes (Fig. 3f). DOR immunoreactivity was also identified inside myocardial cells of the right ventricle (Fig. $3 \mathrm{~g}$ ). KOR immunoreactivity was demonstrated in the right ventricle and intraventricular septum of human myocardium in sparse fine nerve fibers between cardiomyocytes (Fig. 4a),
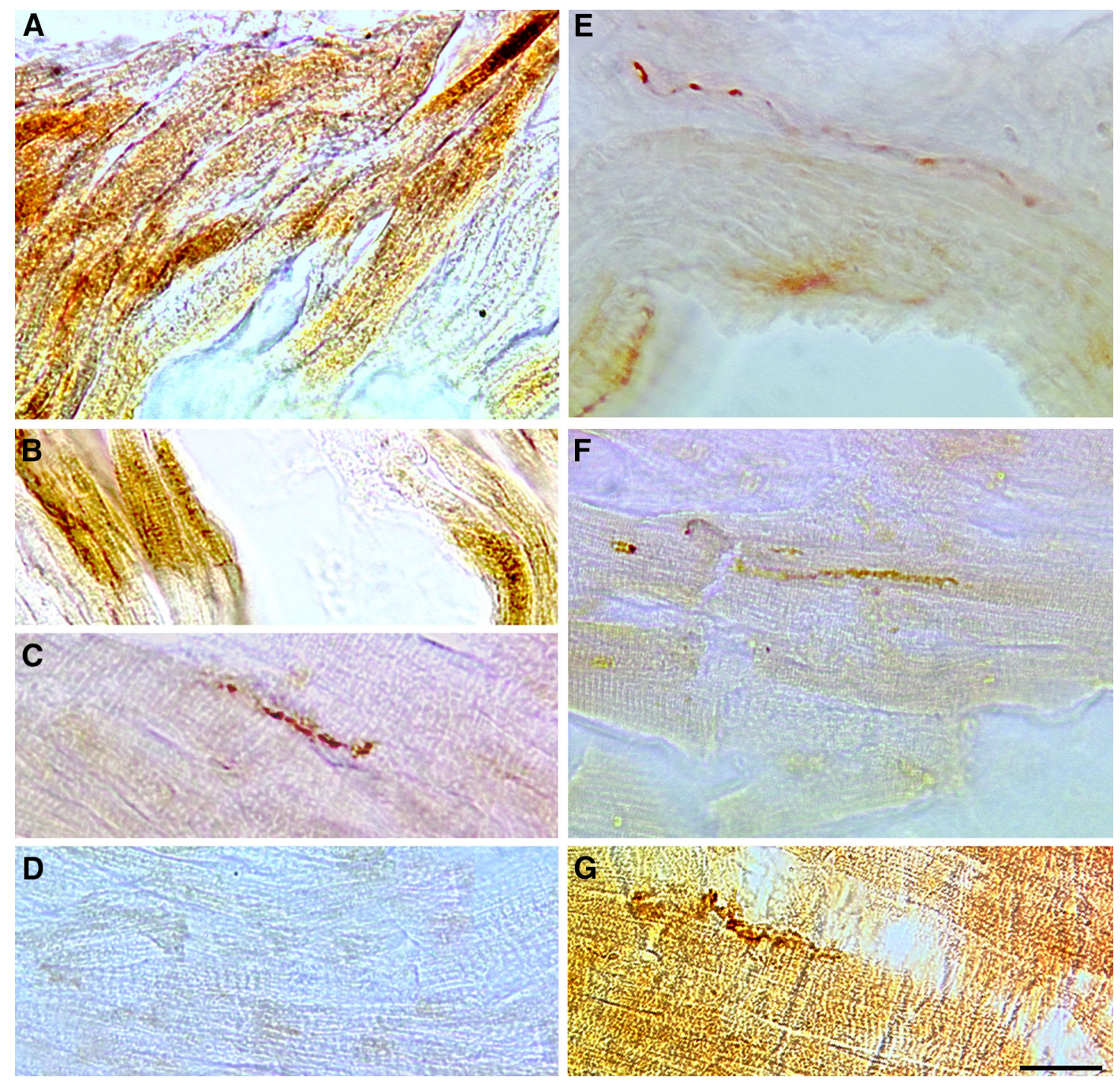

Fig. 3 Immunohistochemical localization of mu opioid receptor (MOR) (a-d) or delta opioid receptor (DOR) $(\mathbf{e}-\mathbf{g})$ in human myocardial tissue. a, b MOR expressed in myocardial cells of the human heart. $\mathbf{c}$ MOR expressed in sparse solitary nerve processes in cardiac tissue. d Preabsorption of antibody against MOR with $5 \mu \mathrm{g} / \mathrm{ml}$

of synthetic peptide antigen for MOR revealed no significant immunoreactivity. $\mathbf{e}-\mathbf{g}$ DOR-immunoreactive nerve fibers in human myocardial tissue was usually sparse, fine, and varicose. $\mathbf{g}$ DOR was expressed in cardiomyocytes of the human heart. Bar $20 \mu \mathrm{m}$ 

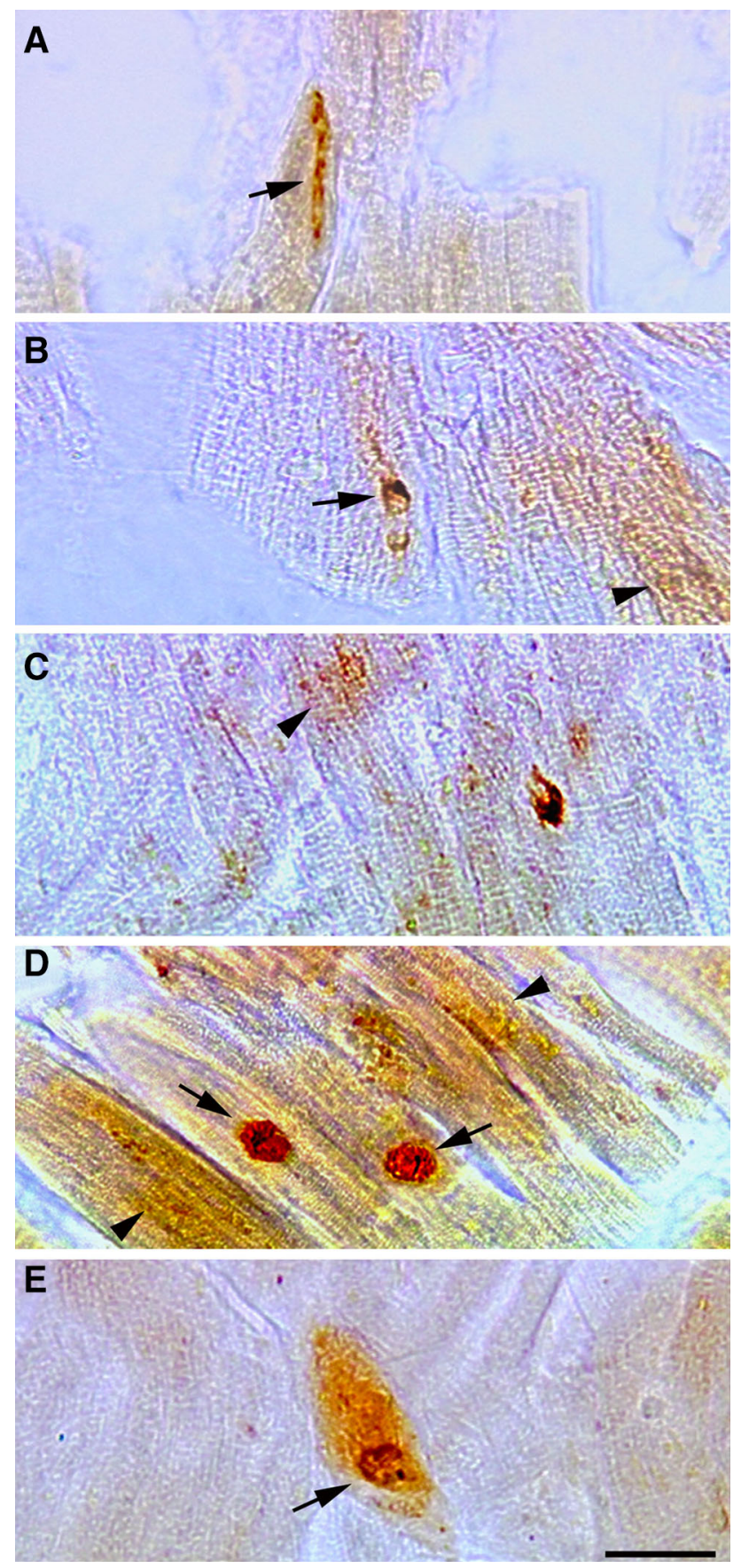

Fig. 4 Immunohistochemical localization of kappa opioid receptor (KOR) (a-e) in human myocardial tissue. a, b KOR was expressed in sparse solitary nerve processes in cardiac tissue (arrow). d, e KOR was expressed on long fusiform cells with an eccentrically located large nucleus (arrow) of the human heart. b-d KOR is expressed in cardiomyocytes (arrowhead) of the human heart. Bar $20 \mu \mathrm{m}$

inside myocardial cells (Fig. 4b-d), and occasionally on long fusiform cells with an eccentrically located large nucleus resembling intrinsic cardiac adrenergic (ICA) celllike structures (Fig. 4d, e). Preabsorption of primary antibodies against MOR, DOR, or KOR with $5 \mu \mathrm{g} / \mathrm{ml}$ of the respective synthetic peptide antigen for MOR, DOR, or KOR as well as the omission of the primary antibody revealed no significant immunoreactivity (Fig. 3d).

Coexpression of DOR in CGRP-IR and PGP9.5-IR neurons of human myocardial tissue

Double immunofluorescence confocal microscopy demonstrated that human myocardium was densely innervated by the general neuronal marker PGP9.5-IR (fluorescein isothiocyanate (FITC) green) axons (Fig. 5b, e), some of which also displayed DOR (Texas Red) immunoreactivity (Fig. 5a, c, d, f). Some nerve fibers were immunolabeled for PGP9.5 alone (Fig. 5c, f). In addition, double immunofluorescence confocal microscopy of human heart tissue demonstrated afferent nerve fibers coexpressing the sensory neuronal marker CGRP (FITC green) (Fig. 5h, k), which were colocalized with DOR immunoreactivity (Fig. $5 \mathrm{~g}, \mathrm{i}, \mathrm{j}, \mathrm{l})$.

\section{Discussion}

The findings of this study demonstrate for the first time the immunohistochemical localization of all three ORs (MOR, DOR, and KOR) in human myocardial tissue. MOR and DOR immunoreactivity was mainly found in myocardial cells as well as on sparse individual nerve fibers. KOR immunoreactivity was found predominantly in myocardial cells and on ICA cell-like structures. Double immunofluorescence microscopy revealed that DOR colocalized with the neuronal marker PGP9.5 as well as with the sensory neuron marker CGRP. CGRP-IR fibers were detectable either in nerve bundles or as sparse individual nerve fibers containing varicose-like structures.

In earlier studies, the neuropeptide CGRP was demonstrated in nerve fibers of the human heart. The CGRP content in the atria was found to be three- to fourfold higher than that in the ventricles [31]. Wharton et al. [32] confirmed these early findings and reported CGRP immunoreactivity mainly on scattered individual neurons, ganglion neurons, and nerve bundles. Interestingly in the developing human heart, sensory CGRP-IR innervation occurs later (18th-24th week of gestation) than the autonomic parasympathetic and sympathetic ones (7th week of gestation), suggesting a chronological development of the autonomic and sensory nerves $[33,34]$. Peptidergic CGRPIR nerve fibers are part of a complex sensory network that transmits relevant sensory information from the heart to nearby intrinsic cells as well as to the spinal cord [35].

Consistent with our previous studies in rats [16], we can now demonstrate that DORs in the human heart are expressed in CGRP-IR sensory neurons as well as in 

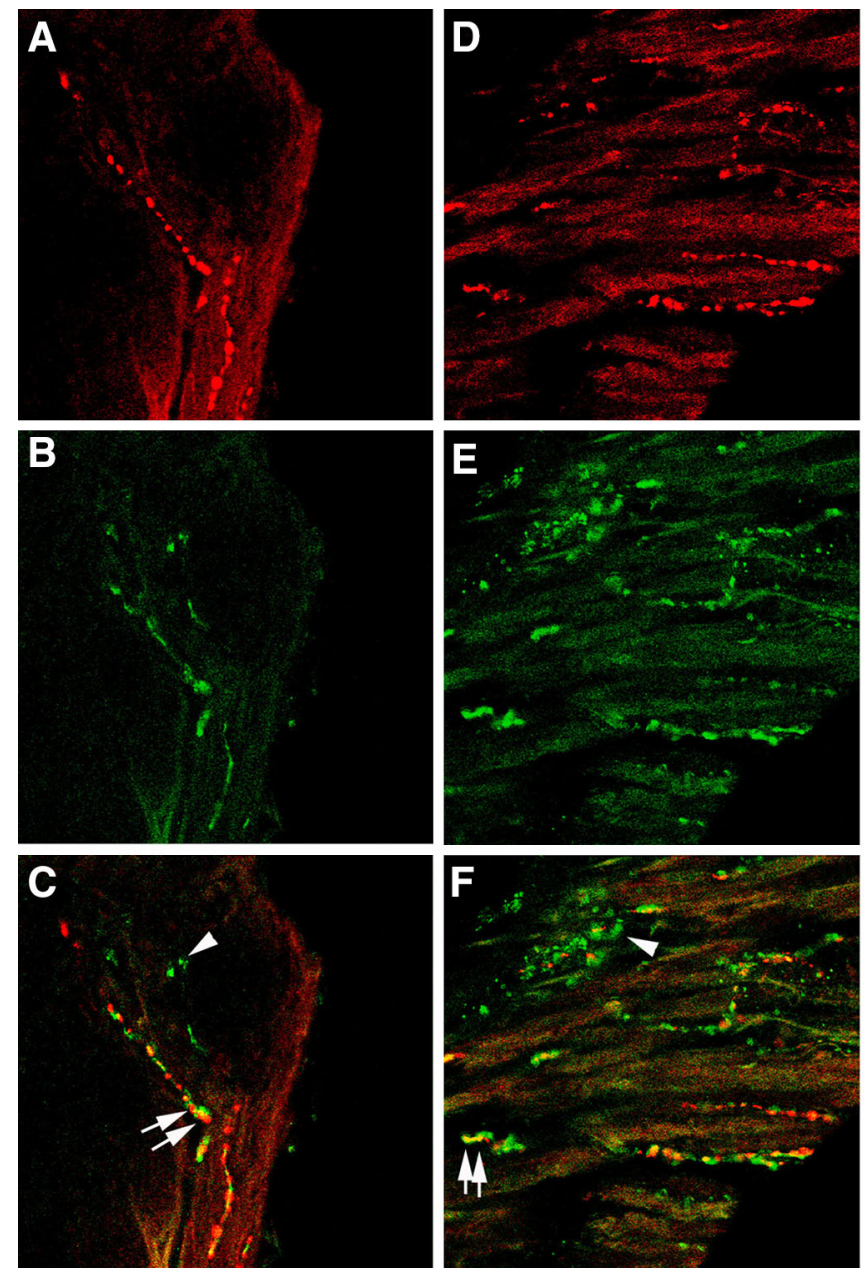

Fig. 5 Confocal microscopy of DOR $(\mathbf{a}, \mathbf{d}, \mathbf{g}, \mathbf{j})$ (red fluorescence) with polyclonal protein gene product 9.5 (PGP9.5) (b, e) or CGRP (h, k) (green fluorescence) double immunofluorescence in human myocardial tissue. c, $\mathbf{f}, \mathbf{i}$ and $\mathbf{l}$ are combined images showing

myocardial cells, suggesting that opioids regulate both the transmission of sensory information and the function of myocardial cells. In addition, we can show the presence of the other ORs (MOR and KOR) on single nerve fibers and on myocardial cells, confirming that all three ORs are expressed in the human heart. Until now, MOR, DOR, and KOR have been mainly identified by the detection of their mRNA in cardiomyocytes [18, 19, 36-38]. Moreover, DOR protein was detected by Western blot and immunohistochemistry in ICA cells [37, 38]. The most interesting previous finding is the demonstration of MOR- and DORspecific binding sites in the heart of human volunteers by the use of MOR- and DOR-specific radioligands and positron emission tomography [39]. The distribution of these binding sites was homogeneous throughout the myocardium, with relatively higher uptake in the lateral wall than in the septum. The specificity of binding was confirmed with naloxone pretreatment, which decreased radioligand uptake.
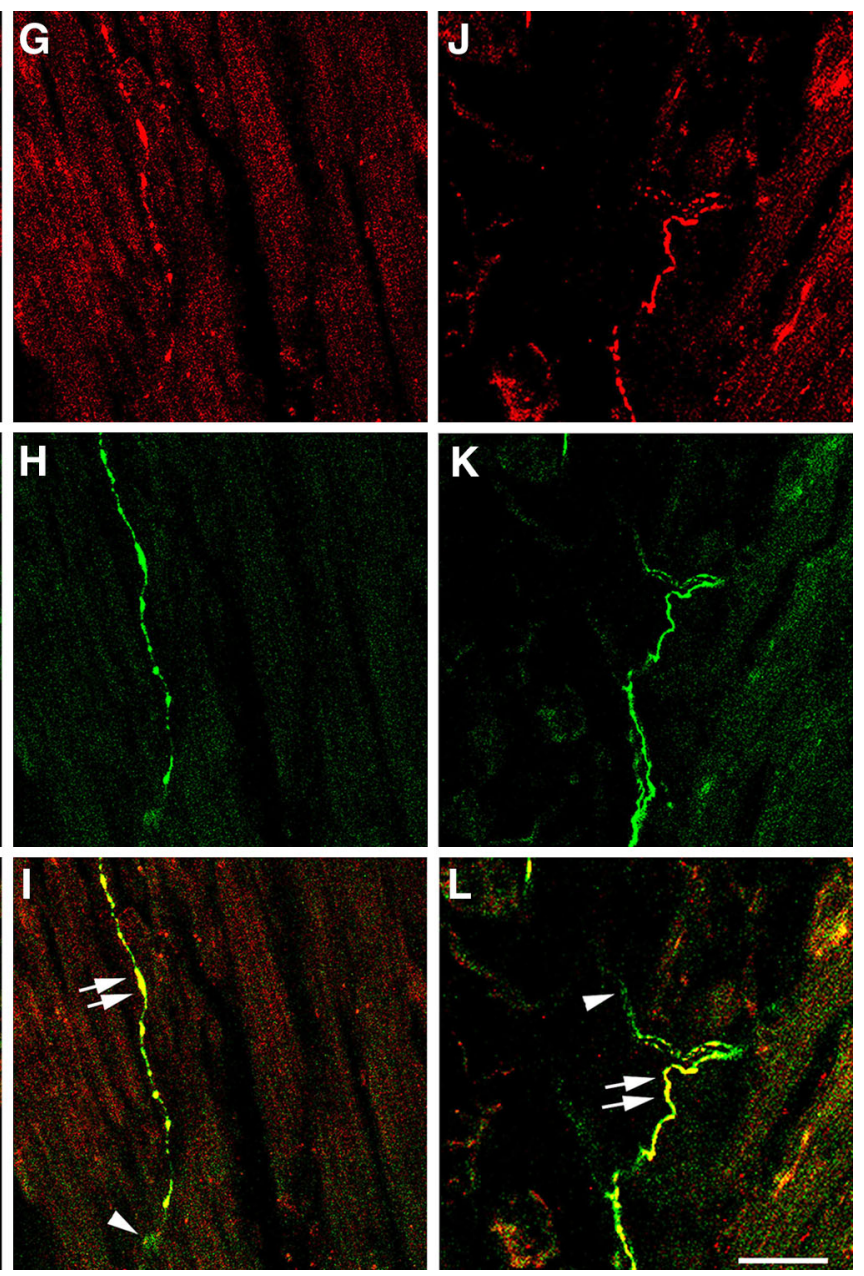

colocalization (double arrows) of DOR with PGP9.5 (c, f) or CGRP (i, l). Some PGP9.5- or CGRP-immunoreactive nerve fibers (arrowheads) do not express DOR. Bar $20 \mu \mathrm{m}$ (color figure online)

There is a growing body of evidence from experimental studies of the rodent heart supporting the notion that activation of the local ORs affects cardiac function. Indeed, ORs such as DOR in the heart elicit cardioprotective effects against myocardial infarction and trigger processes similar to ischemic preconditioning [40, 41]. DOR stimulation also reduces arrhythmias, and preserves the viability of isolated cells and organs [42, 43]. In addition, DOR activation enhances the growth of neonatal rat ventricular myocytes via the extracellular signal-regulated kinase pathway [44] and mediates antiapoptotic effects in cardiomyocytes [45]. KOR stimulation is proarrhythmic in swine [46], but in rats it can exert a pro- or antiarrhythmic influence [47-50]. In rabbit hearts, KOR agonists inhibit electric stimulation-induced sympathomimetic effects [51], whereas in rats MOR activation did not induce preconditioning [52, 53].

It is well established that endogenous ligands for ORs, i.e., the opioid peptides encephalin and dynorphin and their 
precursor peptides proenkephalin and prodynorphin, are expressed in peripheral neuronal terminals of the human heart [54, 55] and that of other mammalian species, including the rat (for a review, see $[56,57]$ ). However, the release of opioid peptides (i.e., OR ligands) from heart tissue has not been conclusively demonstrated although preliminary evidence supports this view [58, 59]. Thus, in the human heart there exists an intrinsic opioid system that may regulate the parasympathetic and sympathetic control of the heart as well as myocardial performance. However, our study has its limitations as tissue samples were taken within $48 \mathrm{~h}$ post mortem, which may contribute to a potential loss of antigen recognition. Nevertheless, our results remain in concordance with previous studies showing the existence of ORs in the human heart by other techniques [18, 19, 32, 36, 37].

Taken together, our findings demonstrate that ORs in the human heart are expressed in CGRP-IR sensory nerves, as well as in myocardial cells and small cells resembling ICA cells, suggesting a modulatory role of opioids both in the neural transmission and in the function of myocardial cells. This study may stimulate further experiments to investigate systematically the precise subcellular localization of each OR subtype in the human heart.

Acknowledgments We are very grateful for the gift of antibodies from Drs S. Schulz and V. Höllt, Magdeburg, Germany (MOR) and Dr S.J. Watson, Ann Arbor, Michigan, USA (KOR), and for the support of Ben Zylicz.

\section{References}

1. Verma-Gandhu M, Verdu EF, Bercik P, Blennerhassett PA, AlMutawaly N, Ghia JE, Collins SM (2007) Visceral pain perception is determined by the duration of colitis and associated neuropeptide expression in the mouse. Gut 56:358-364

2. Krajnik M, Podolec Z, Siekierka M, Sykutera M, Pufal E, Sobanski P, Makarewicz R, Neef C, Punt N, Zylicz Z (2009) Morphine inhalation by cancer patients: a comparison of different nebulization techniques using pharmacokinetic, spirometric, and gasometric parameters. J Pain Symp Manag 38:747-757

3. Mahler DA, Murray JA, Waterman LA, Ward J, Kraemer WJ, Zhang X, Baird JC (2009) Endogenous opioids modify dyspnoea during treadmill exercise in patients with COPD. Eur Respir J 33:771-777

4. Barry U, Zuo Z (2005) Opioids: old drugs for potential new applications. Curr Pharm Des 11:1343-1350

5. Wong GT, Ling Ling J, Irwin MG (2010) Activation of central opioid receptors induces cardioprotection against ischemiareperfusion injury. Anesth Analg 111:24-28

6. Zatta AJ, Kin H, Yoshishige D, Jiang R, Wang N, Reeves JG, Mykytenko J, Guyton RA, Zhao ZQ, Caffrey JL, Vinten-Johansen J (2008) Evidence that cardioprotection by postconditioning involves preservation of myocardial opioid content and selective opioid receptor activation. Am J Physiol Heart Circ Physiol 294:H1444-H1451

7. Park J, Ann S, Chung H, Lee J, Kim S-J, Garg S, Shin E-S (2013) Remote ischemic preconditioning in hemodialysis: a pilot study. Heart Vessels. doi:10.1007/s00380-013-0329-y
8. Peart JN, Gross GJ (2004) Morphine-tolerant mice exhibit a profound and persistent cardioprotective phenotype. Circulation 109:1219-1222

9. Liang BT, Gross GJ (1999) Direct preconditioning of cardiac myocytes via opioid receptors and KATP channels. Circ Res 84:1396-1400

10. Shimizu M, Tropak M, Diaz RJ, Suto F, Surendra H, Kuzmin E, Li J, Gross G, Wilson GJ, Callahan J, Redington AN (2009) Transient limb ischaemia remotely preconditions through a humoral mechanism acting directly on the myocardium: evidence suggesting cross-species protection. Clin Sci (Lond) 117:191-200

11. Bolte C, Newman G, Schultz Jel J (2009) Hypertensive state, independent of hypertrophy, exhibits an attenuated decrease in systolic function on cardiac kappa-opioid receptor stimulation. Am J Physiol Heart Circ Physiol 296:H967-H975

12. Bolte C, Newman G, Schultz Jel J (2009) Kappa and delta opioid receptor signaling is augmented in the failing heart. J Mol Cell Cardiol 47:493-503

13. Laurent S, Marsh JD, Smith TW (1985) Enkephalins have a direct positive inotropic effect on cultured cardiac myocytes. Proc Natl Acad Sci 82:5930-5934

14. Balasubramanian S, Ramakrishnan S, Charboneau R, Wang J, Barke R, Roy S (2001) Morphine sulfate inhibits hypoxiainduced vascular endothelial growth factor expression in endothelial cells and cardiac myocytes. J Mol Cell Cardiol 33:2179-2187

15. Zhao S-H, Gao H-Q, Ji X, Wang Y, Liu X-J, You B-A, Cui X-P, Qiu J (2013) Effect of ouabain on myocardial ultrastructure and cytoskeleton during the development of ventricular hypertrophy. Heart Vessels 28:101-113

16. Mousa SA, Shaqura M, Schaper J, Treskatsch S, Habazettl H, Schafer M, Abdul-Khaliq H (2011) Developmental expression of delta-opioid receptors during maturation of the parasympathetic, sympathetic, and sensory innervations of the neonatal heart: early targets for opioid regulation of autonomic control. J Comp Neurol 519:957-971

17. Mousa SA, Shaqura M, Schaper J, Huang W, Treskatsch S, Habazettl H, Abdul-Khaliq H, Schafer M (2010) Identification of mu- and kappa-opioid receptors as potential targets to regulate parasympathetic, sympathetic, and sensory neurons within rat intracardiac ganglia. J Comp Neurol 518:3836-3847

18. Bell SP, Sack MN, Patel A, Opie LH, Yellon DM (2000) Delta opioid receptor stimulation mimics ischemic preconditioning in human heart muscle. J Am Coll Cardiol 36:2296-2302

19. Mcdonald J, Leonard AD, Serrano-Gomez A, Young SP, Swanevelder J, Thompson JP, Lambert DG (2010) Assessment of nociceptin/orphanin FQ and $\mu$-opioid receptor mRNA in the human right atrium. Br J Anaesth 104:698-704

20. Peng J, Sarkar S, Chang SL (2012) Opioid receptor expression in human brain and peripheral tissues using absolute quantitative real-time RT-PCR. Drug Alcohol Depend 124:223-228

21. Mousa SA, Straub RH, Schafer M, Stein C (2007) Beta-endorphin, Met-enkephalin and corresponding opioid receptors within synovium of patients with joint trauma, osteoarthritis and rheumatoid arthritis. Ann Rheum Dis 66:871-879

22. Mousa SA, Cheppudira BP, Shaqura M, Fischer O, Hofmann J, Hellweg R, Schafer M (2007) Nerve growth factor governs the enhanced ability of opioids to suppress inflammatory pain. Brain: J Neurol 130:502-513

23. Riedl MS, Schnell SA, Overland AC, Chabot-Dore AJ, Taylor AM, Ribeiro-Da-Silva A, Elde RP, Wilcox GL, Stone LS (2009) Coexpression of alpha 2A-adrenergic and delta-opioid receptors in substance P-containing terminals in rat dorsal horn. J Comp Neurol 513:385-398

24. Zhu Y, King MA, Schuller AG, Nitsche JF, Reidl M, Elde RP, Unterwald E, Pasternak GW, Pintar JE (1999) Retention of 
supraspinal delta-like analgesia and loss of morphine tolerance in delta opioid receptor knockout mice. Neuron 24:243-252

25. Arvidsson U, Riedl M, Chakrabarti S, Lee JH, Nakano AH, Dado RJ, Loh HH, Law PY, Wessendorf MW, Elde R (1995) Distribution and targeting of a mu-opioid receptor (MOR1) in brain and spinal cord. J Neurosci 15:3328-3341

26. Arvidsson U, Dado RJ, Riedl M, Lee JH, Law PY, Loh HH, Elde R, Wessendorf MW (1995) delta-Opioid receptor immunoreactivity: distribution in brainstem and spinal cord, and relationship to biogenic amines and enkephalin. J Neurosci 15:1215-1235

27. Schulz S, Schreff M, Koch T, Zimprich A, Gramsch C, Elde R, Hollt V (1998) Immunolocalization of two mu-opioid receptor isoforms (MOR1 and MOR1B) in the rat central nervous system. Neuroscience 82:613-622

28. Brack A, Rittner HL, Machelska H, Shaqura M, Mousa SA, Labuz D, Zollner C, Schafer M, Stein C (2004) Endogenous peripheral antinociception in early inflammation is not limited by the number of opioid-containing leukocytes but by opioid receptor expression. Pain 108:67-75

29. Krajnik M, Schafer M, Sobanski P, Kowalewski J, Bloch-Boguslawska E, Zylicz Z, Mousa SA (2010) Local pulmonary opioid network in patients with lung cancer: a putative modulator of respiratory function. Pharmacol Rep 62:139-149

30. Mousa SA, Krajnik M, Sobanski P, Kowalewski J, Bloch-Boguslawska E, Zylicz Z, Schafer M (2010) Dynorphin expression, processing and receptors in the alveolar macrophages, cancer cells and bronchial epithelium of lung cancer patients. Histol Histopathol 25:755-764

31. Franco-Cereceda A, Lundberg JM, Hokfelt T (1986) Somatostatin: an inhibitory parasympathetic transmitter in the human heart? Eur J Pharmacol 132:101-102

32. Wharton J, Polak JM, Gordon L, Banner NR, Springall DR, Rose M, Khagani A, Wallwork J, Yacoub MH (1990) Immunohistochemical demonstration of human cardiac innervation before and after transplantation. Circ Res 66:900-912

33. Chow LT, Chow SS, Anderson RH, Gosling JA (1993) Innervation of the human cardiac conduction system at birth. Br Heart J 69:430-435

34. Gordon L, Polak JM, Moscoso GJ, Smith A, Kuhn DM, Wharton J (1993) Development of the peptidergic innervation of human heart. J Anat 183(Pt 1):131-140

35. Adams DJ, Cuevas J (2004) Electrophysiological properties of intrinsic cardiac neurons. In: Armour JA, Ardell JL (eds) Basic and clinical neurocardiology. Oxford University Press, New York, pp 1-60

36. Lendeckel U, Muller C, Rocken C, Laube B, Tager M, Huth C, Klein HU, Goette A (2005) Expression of opioid receptor subtypes and their ligands in fibrillating human atria. Pacing Clin Electrophysiol 28(Suppl 1):S275-S279

37. Huang MH, Wang HQ, Roeske WR, Birnbaum Y, Wu Y, Yang NP, Lin Y, Ye Y, Mcadoo DJ, Hughes MG, Lick SD, Boor PJ, Lui CY, Uretsky BF (2007) Mediating delta-opioid-initiated heart protection via the beta2-adrenergic receptor: role of the intrinsic cardiac adrenergic cell. Am J Physiol Heart Circ Physiol 293:H376-H384

38. Huang MH, Nguyen V, Wu Y, Rastogi S, Lui CY, Birnbaum Y, Wang HQ, Ware DL, Chauhan M, Garg N, Poh KK, Ye L, Omar AR, Tan HC, Uretsky BF, Fujise K (2009) Reducing ischaemia/reperfusion injury through delta-opioid-regulated intrinsic cardiac adrenergic cells: adrenopeptidergic co-signalling. Cardiovasc Res 84:452-460

39. Villemagne PS, Dannals RF, Ravert HT, Frost JJ (2002) PET imaging of human cardiac opioid receptors. Eur J Nucl Med Mol Imaging 29:1385-1388

40. Gross GJ (2003) Role of opioids in acute and delayed preconditioning. J Mol Cell Cardiol 35:709-718

41. Schultz JE, Gross GJ (2001) Opioids and cardioprotection. Pharmacol Ther 89:123-137
42. Takasaki Y, Wolff RA, Chien GL, Van Winkle DM (1999) Met5enkephalin protects isolated adult rabbit cardiomyocytes via delta-opioid receptors. Am J Physiol 277:H2442-H2450

43. Lonergan T, Goodchild AK, Christie MJ, Pilowsky PM (2003) Presynaptic delta opioid receptors differentially modulate rhythm and pattern generation in the ventral respiratory group of the rat. Neuroscience 121:959-973

44. Zhao M, Wang HX, Yang J, Su YH, Su RJ, Wong TM (2008) delta-Opioid receptor stimulation enhances the growth of neonatal rat ventricular myocytes via the extracellular signal-regulated kinase pathway. Clin Exp Pharmacol Physiol 35:97-102

45. Yao LL, Wang YG, Cai WJ, Yao T, Zhu YC (2007) Survivin mediates the anti-apoptotic effect of delta-opioid receptor stimulation in cardiomyocytes. J Cell Sci 120:895-907

46. Coles JA Jr, Sigg DC, Iaizzo PA (2003) Role of kappa-opioid receptor activation in pharmacological preconditioning of swine. Am J Physiol Heart Circ Physiol 284:H2091-H2099

47. Aitchison KA, Baxter GF, Awan MM, Smith RM, Yellon DM, Opie LH (2000) Opposing effects on infarction of delta and kappa opioid receptor activation in the isolated rat heart: implications for ischemic preconditioning. Basic Res Cardiol 95:1-10 (discussion 11)

48. Cao Z, Liu L, Van Winkle DM (2003) Activation of delta- and kappa-opioid receptors by opioid peptides protects cardiomyocytes via KATP channels. Am J Physiol Heart Circ Physiol 285:H1032-H1039

49. Wang GY, Wu S, Pei JM, Yu XC, Wong TM (2001) Kappa- but not delta-opioid receptors mediate effects of ischemic preconditioning on both infarct and arrhythmia in rats. Am J Physiol Heart Circ Physiol 280:H384-H391

50. Wong TM, Lee AY, Tai KK (1990) Effects of drugs interacting with opioid receptors during normal perfusion or ischemia and reperfusion in the isolated rat heart—an attempt to identify cardiac opioid receptor subtype(s) involved in arrhythmogenesis. J Mol Cell Cardiol 22:1167-1175

51. Starke K, Schoffel E, Illes P (1985) The sympathetic axons innervating the sinus node of the rabbit possess presynaptic opioid kappa- but not mu- or delta-receptors. Naunyn Schmiedebergs Arch Pharmacol 329:206-209

52. Schultz JE-J, Hsu AK, Nagase H, Gross GJ (1998) TAN-67, a delta 1-opioid receptor agonist, reduces infarct size via activation of Gi/o proteins and KATP channels. Am J Physiol 274:H909-H914

53. Wu S, Li HY, Wong TM (1999) Cardioprotection of preconditioning by metabolic inhibition in the rat ventricular myocyte. Involvement of kappa-opioid receptor. Circ Res 84:1388-1395

54. Rechardt L, Aalto-Setala K, Purjeranta M, Pelto-Huikko M, Kyosola K (1986) Peptidergic innervation of human atrial myocardium: an electron microscopical and immunocytochemical study. J Auton Nerv Syst 17:21-32

55. Kyosola K, Aalto-Setala K, Harjula A, Mattila S, Rechardt L (1986) Substance P- and leu-enkephalin-immunoreactive nerves before and after myocardial ischaemia, hypothermic chemical cardioplegia and reperfusion injury during open-heart surgery. Scand J Thorac Cardiovasc Surg 20:89-92

56. Ventura C, Pintus G, Tadolini B (1998) Opioid peptide gene expression in the myocardial cell. Trends Cardiovasc Med 8:102-110

57. Wilson SP, Klein RL, Chang KJ, Gasparis MS, Viveros $\mathrm{OH}$, Yang WH (1980) Are opioid peptides co-transmitters in noradrenergic vesicles of sympathetic nerves? Nature 288:707-709

58. Younes A, Pepe S, Yoshishige D, Caffrey JL, Lakatta EG (2005) Ischemic preconditioning increases the bioavailability of cardiac enkephalins. Am J Physiol Heart Circ Physiol 289:H1652-H1661

59. Younes A, Pepe S, Barron BA, Spurgeon HA, Lakatta EG, Caffrey JL (2000) Cardiac synthesis, processing, and coronary release of enkephalin-related peptides. Am J Physiol Heart Circ Physiol 279:H1989-H1998 